\title{
De zoete inval
}

Citation for published version (APA):

Schalkwijk, C. G. (2012). De zoete inval. Maastricht University. https://doi.org/10.26481/spe.20120516cs

Document status and date:

Published: 16/05/2012

DOI:

10.26481/spe.20120516cs

Document Version:

Publisher's PDF, also known as Version of record

\section{Please check the document version of this publication:}

- A submitted manuscript is the version of the article upon submission and before peer-review. There can be important differences between the submitted version and the official published version of record.

People interested in the research are advised to contact the author for the final version of the publication, or visit the DOI to the publisher's website.

- The final author version and the galley proof are versions of the publication after peer review.

- The final published version features the final layout of the paper including the volume, issue and page numbers.

Link to publication

\footnotetext{
General rights rights.

- You may freely distribute the URL identifying the publication in the public portal. please follow below link for the End User Agreement:

www.umlib.nl/taverne-license

Take down policy

If you believe that this document breaches copyright please contact us at:

repository@maastrichtuniversity.nl

providing details and we will investigate your claim
}

Copyright and moral rights for the publications made accessible in the public portal are retained by the authors and/or other copyright owners and it is a condition of accessing publications that users recognise and abide by the legal requirements associated with these

- Users may download and print one copy of any publication from the public portal for the purpose of private study or research.

- You may not further distribute the material or use it for any profit-making activity or commercial gain

If the publication is distributed under the terms of Article $25 \mathrm{fa}$ of the Dutch Copyright Act, indicated by the "Taverne" license above, 
Mijnheer de pro-rector, waarde collega's, lieve familieleden en vrienden,

Ik ben geboren op de Kanis (dia 2): een kleine buurtschap behorend tot het dorp Kamerik op ca $20 \mathrm{~km}$ van Utrecht. Ik ben daar ook opgegroeid. Het enige wat me toen echt bezig hield was sport; ik voetbalde dag en nacht. En niet onverdienstelijk; tenminste dat vond ik. In de winter schaatste ik veel. Op jonge leeftijd was mijn ambitie dan ook om topsporter te worden. En dat is gelukt; wetenschap is topsport. Ik wil u de komende 3 kwartier meenemen in de wonderlijke wereld van wetenschap.

Voor u staat een bijzonder hoogleraar experimentele interne geneeskunde. Dit bijzondere slaat dus niet op de persoon, maar op de leerstoel. De leerstoel is niet experimenteel of tijdelijk van aard; het slaat op experimenteel onderzoek en wel in het vakgebied de Interne Geneeskunde. De interne geneeskunde houdt zich bezig met ziekten van de inwendige organen. Dit vakgebied is breed, heel breed. In lijn met Hippocrates (dia 3), die wordt beschouwd als de grondlegger van de Westerse geneeskunde, zal deze rede ook gaan over balans. Hij was toen al overtuigd dat gezondheid bij de mens afhing van balans; disbalans zou ziekte veroorzaken.

Ik wil u meenemen naar één van de grootste gezondheidsproblemen van deze tijd die voortkomt uit disbalans; overgewicht en diabetes en het hieruit voortkomende hoge risico voor hart- en vaatziekten. Ik ga u een overzicht geven van onze bijdrage aan dit onderzoek. Ik zal ingaan op de belangrijke rol van versuikering van eiwitten in de as overgewicht, diabetes, en hart en vaatziekten. Dat is de kern van mijn zaak. Ik zal u proberen te overtuigen van het belang van deze versuikerde eiwitten voor onze gezondheid en ik kan u nu al verklappen; dit gaat verder dan alleen diabetes.

Maar laten we eens een gedachte-experiment doen waarin we 10-duizenden jaren terug gaan in de tijd. We bevinden ons in de rijke natuur. Er wordt gejaagd. Als je goed naar deze mensen kijkt, zie je dat ze fit en slank zijn (dia 4). De gezondheidsproblemen begonnen langzaamaan zo'n 10.000 jaar geleden toen de mens een vaste plek ging zoeken om te wonen. Men ging minder jagen en de diversiteit van het dieet nam af. Het maakte de mens gevoeliger voor chronische ziekten. De laatste 100 jaar zijn deze veranderingen enorm snel gegaan. Omdat genetische aanpassing op veranderingen van omgevingsfactoren tenminste 25.000 jaar op die veranderingen achterloopt, is het toch ook niet verwonderlijk dat ons lichaam daar op reageert met allerlei kwalen als gevolg ${ }^{1}$

De evolutionaire hypothese komt het dichtst bij een verklaring van de recente epidemie van overgewicht. In tijden toen het voedsel schaars was, was de capaciteit om uit zeldzame periodes van overvloed, dus een succesvolle oogst of jachtpartij, voordeel te halen door energie op te slaan ongetwijfeld een evolutionair voordeel. Mensen aten zich vol om een voorraad te hebben voor barre tijden. Dit is precies het tegengestelde van wat er nu speelt in de maatschappij (dia 5). daar voedsel altijd en overal in grote hoeveelheden beschikbaar is.

Dit wordt geïllustreerd door de geschiedenis van volkeren welke eeuwenlang in schaarste hebben geleefd en nu meer voedsel tot hun beschikking hebben. Het beste voorbeeld hiervan zijn de mensen op het eiland Nauru (Naoero) (dia 6), in de buurt van Australië. Nauru telt 14.000 inwoners en is ongeveer half zo groot als mijn geliefde Waddeneiland Schiermonnikoog. De eerste bewoners van Nauru waren in staat tot de grote oversteek naar het vaste land met zeekano's, doordat zij weinig voedsel snel opsloegen als vet en dit weer langzaam verbrandden. Sinds enkele decennia is de welvaart enorm toegenomen door de winning van fosfaat op het eiland, waardoor men er Westers ging eten. Er werd zelfs een vliegveld aangelegd en kano's waren niet meer nodig. Dit maakte in de loop der tijden Nauru steeds welvarender. Dat dat niet strookt met hun natuurlijke aanleg, blijkt uit het feit dat inmiddels $90 \%$ van de mensen op Nauru overgewicht heeft en $40 \%$ diabetes; de hoogste cijfers ter wereld.

Het ontwikkelen van obesitas en diabetes is dus multifactorieel bepaald; er lijkt sprake van een zekere aanleg met daar bovenop een verkeerd voedingspatroon, te veel eten en te weinig bewegen. Het is van alles wat. Belangrijke fracties van de bevolking in de wereld zijn nu zwaarlijvig (dia 7). In Nederland was in 2009 47\% van de volwassenen boven de twintig jaar te zwaar $^{4}$. Zeer zorgelijk is dat cijfers afkomstig uit 2010 laat zien dat ook van de jeugd van 2 tot 21 jaar $14 \%$ overgewicht heeft en $2 \%$ ernstig overgewicht ${ }^{5}$ 
Overgewicht zorgt voor een sterke toename van het risico op diabetes en hart- en vaatziekten. Recent is geschat dat ongeveer één op de zeven gevallen van hart- en vaatziekten in Nederland toegeschreven kan worden aan overgewicht ${ }^{9}$. Gebaseerd op data van grote studies ${ }^{6,7}$ zien we dat volwassenen met een body mass index (BMI) van rond de 35 de kans op het krijgen van diabetes bijna 100 keer zo hoog is als volwassenen met een BMl van rond de 20. Maar ook bij overgewicht is de kans nog 15 keer hoger op het krijgen van diabetes (dia 8).

Diabetes ofwel suikerziekte wordt gekarakteriseerd door een te hoge glucose concentratie in het bloed. Normaal regelt het lichaam de bloedsuikerspiegel heel precies met het hormoon insuline. Insuline is nodig voor de opname van glucose uit het bloed in de cellen. En in de cellen is glucose nodig voor de energievoorziening. Glucose is dus onmisbaar. Bij diabetes is het lichaam niet meer in staat om glucose goed te verwerken. We onderscheiden twee type diabetes. Bij type 1 diabetes maken de $\beta$-cellen in de eilandjes van Langerhans in de alvleesklier onvoldoende insuline aan ten gevolge van een auto-immuunreactie van het eigen afweersysteem tegen deze $\beta$-cellen. Bij type 2 diabetes oftewel ouderdomssuiker reageert het lichaam onvoldoende op de aanwezige insuline en dat noemen we insuline resistentie. Hierdoor ontstaat op den duur een te hoog glucosegehalte in het bloed en dus type 2 diabetes. Insuline resistentie wordt beschouwd een voorstadium van diabetes. En juist overgewicht leidt tot insuline resistentie en uiteindelijk dus tot type 2 diabetes.

Een zeer voor de hand liggende vraag is hoe overgewicht nu leidt tot diabetes. Hoewel we het antwoord nog niet weten is een belangrijke hypothese dat er vanuit het buikvet allerlei stoffen worden vrijgemaakt die in het lichaam kunnen leiden tot ontstekingsreacties en ongevoeligheid van cellen voor insuline, type 2 diabetes en hart en vaatziekten (dia 9). Ik kom hier later nog op terug temeer wij sterke aanwijzingen hebben dat versuikerde eiwitten een belangrijke rol spelen in het vrijmaken van die stofjes in het buikvet die dus kunnen leiden tot insuline resistentie en type 2 diabetes

Diabetes is de meest voorkomende ziekte in Nederland. In totaal zijn er in Nederland zo'n miljoen mensen met diabetes. Het aantal Nederlanders met diabetes is tussen 2000 en 2007 met ruim $80 \%$ gestegen. Als het zo doorgaat, zullen in 2025 ruim 1,3 miljoen Nederlanders de diagnose diabetes hebben ${ }^{10}$. Een belangrijk deel van deze stijging is toe te schrijven aan de groei van het aantal mensen met overgewicht. Negen op de tien mensen met diabetes hebben type 2 diabetes. Eén op de tien heeft diabetes type 1.

Diabetes is nog steeds een onderschatte ziekte; je gaat er niet aan dood. Beste mensen, dit is een cruciale misvatting. Zo overlijden in Nederland jaarlijks evenveel mensen aan diabetes als aan borstkanker, namelijk ruim 3.000. Dat zijn 8 mensen per dag. Veel mensen met diabetes krijgen te maken hart- en vaatziekten veroorzaakt door slecht functionerende kleine bloedvaten en grote bloedvaten (dia 10).

Afwijkingen in de kleinste bloedvaatjes in de nier, ogen en de zenuwen zijn de belangrijkste oorzaak van het optreden van lange termijn complicaties zoals blindheid, nierfalen en zenuwaandoeningen. Naarmate de diabetesduur vordert zal ca 50 tot $80 \%$ van de mensen met diabetes complicaties aan ogen en zenuwen ontwikkelen en ca 30 tot $40 \%$ complicaties aan de nieren. Een optimale glucose instelling verkleint de kans op het ontstaan van deze complicaties aan de kleinste bloedvaatjes.

Afwijking van de grote vaten bij diabetes bestaat voornamelijk uit een versnelde vorm van atherosclerose, oftewel aderverkalking, in de grote slagaders van het hart, de hals en de benen, met als gevolg een verhoogd risico op een hartinfarct, beroerte en vaatlijden aan de benen. Naast glucose lijkt het risico hierop ook afhankelijk te zijn van andere risicofactoren zoals leeftijd, roken en overgewicht

Goed functionerende bloedvaten zijn dus enorm belangrijk. Met verschillende technieken (dia 11) hebben we kunnen aantonen dat diabetes gepaard gaat met disfunctie van de bloedvaten. Als één van de eersten toonde Dr Ronald Henry aan in een grote studie, de Hoorn studie, dat er sprake is van minder goed functionerende bloedvaten in type 2 diabetes, gemeten als een verminderde vaatverwijding van de grote vaten Deze technieken van vaatfunctiemetingen zullen we de komende jaren ook verder uitbreiden en verfijnen. Eén van de aandachtsgebieden binnen de zal zijn het verder optimaliseren en valideren van zulk soort vaatfunctiemetingen van de grote 
en ook van de kleine vaten om te komen tot een beter begrip over de oorzaken van vaatdisfuncties en dus uiteindelijk hart- en vaatziekten.

Naast deze directe vaatfunctiemetingen hebben we nog een tweede techniek beschikbaar om een indicatie te krijgen over het functioneren van onze bloedvaten. Dit betreft biomarker metingen in het bloed. Het niet goed functioneren van bloedvaten gaat namelijk gepaard met het uitscheiden van specifieke stofjes uit deze bloedvaten in het bloed en deze stofjes, biomarkers genoemd, kunnen we in het bloed meten met geavanceerde analytische technieken. Wij hebben de laatste 10 jaar veel kennis opgebouwd met het meten van zulk soort biomarkers in het bloed. Met deze techniek hebben wij in veel verschillende grote studies aangetoond dat in het bloed van diabetes patiënten, biomarkers van vaatdisfunctie verhoogd aanwezig zijn. Er is de laatste jaren veel inzicht verkregen uit zulk soort epidemiologisch onderzoek. Ik denk dat wij één van de betere labs in de wereld hebben met de juiste analytische en epidemiologische methodieken, voor het meten en verder analyseren van zulk soort biomarkers, waarbij de metingen worden uitgevoerd onder regie van Marjo van de Waarenburg en de epidemiologische analyses onder de hoede van Dr Isabel Ferreira. Beter kan niet.

Dus zowel vaatfunctiemetingen als biomarkers in het bloed laten zien dat diabetes geassocieerd is met slecht functionerende vaten. Een belangrijke onderzoeksvraag is hoe diabetes leidt tot slecht functionerende bloedvaten? Onze onderzoeksfocus van de laatste decennia is er ook op gericht om de processen die kunnen leiden tot complicaties aan de bloedvaten te ontrafelen met een speciale aandacht voor het endotheel. Het endotheel vormt de biologisch actieve binnenbekleding van bloedvaten (dia 12). De eerder genoemde biomarkers in het bloed zijn met name een weergave van het disfunctioneren van het endotheel in de bloedvaten. In de jaren '90 werd al door Prof Coen Stehouwer en anderen aangetoond dat een stijging van biomarkers van endotheeldisfunctie voorafgaat aan het ontstaan van complicaties aan de bloedvaten in type 2 diabetes. Mijn inziens één van de belangrijkste bevindingen in dit veld en nog steeds hét concept waarmee complicaties van de bloedvaten kan worden verklaard, in ieder geval voor een groot deel. Complicaties van de bloedvaten beginnen dus met disfunctioneren van endotheelcellen

De ontdekking van de techniek in de jaren 70 om endotheelcellen te laten groeien buiten het lichaam in kweekschaaltjes heeft de basis gevormd voor onze huidige kennis over al de functies van het endotheel ${ }^{13}$. Vanaf dat moment werden gedetailleerde studies van endotheelfunctie pas uitvoerbaar. Ik ben in de gelukkige omstandigheid geweest om deze techniek te leren van prof Victor van Hinsbergh bij TNO in Leiden, mijn inziens de bakermat van het endotheel onderzoek in Nederland. Op deze dia (dia 13) zien we de zeer gezonde endotheelcellen van mijn middelste zoon Raven die we hebben opgekweekt uit bloedvaten van zijn navelstreng, verkregen direct na zijn geboorte.

Met deze techniek zijn we veel te weten gekomen over de vele functies van het endotheel. Vanaf de jaren '70 is het steeds duidelijker geworden dat dit flinterdunne laagje van endotheelcellen de regie voert over een groot aantal processen in de vaatwand die van essentieel belang zijn voor het functioneren van het organisme. Zo regelt het endotheel actief welke stoffen worden opgenomen uit het bloed, is het ook mede- verantwoordelijk voor de bloeddruk, en ook bij de bloedstolling speelt het endotheel een zeer belangrijke rol.

Zoals ik eerder heb aangegeven, hoge glucose concentraties spelen een belangrijke rol in het niet goed functioneren van de bloedvaten in diabetes en dus uiteindelijk in het ontstaan van complicaties van hart- en bloedvaten. De toegenomen stroom van glucose zijn via verschillende paden in verband gebracht met het ontstaan van hart- en vaatziekten. Dit is door professor Michael Brownlee uit New York, één van de meest vooraanstaande diabetes onderzoekers in de wereld, voor de eerste keer beschreven ${ }^{14}$ (dia 14). Voor de volledigheid heb ik in het figuur de verschillende paden schematisch weergegeven maar ik zal alleen het laatste pad nader bespreken. Het betreft de niet-enzymatische versuikering van eiwitten. Ik zal dit nu verder toelichten.

In ons lichaam vinden 1000-de kleine biochemische reacties plaats die essentieel zijn voor het leven; zonder deze reacties kunnen we niet bestaan; het zijn de motortjes in ons lichaam. De meeste biochemische reacties kunnen alleen maar plaatsvinden met behulp van enzymen; in feite de katalysatoren van deze motortjes. Toch blijken suikers ook spontaan, dus zonder hulp 
van enzymen, te kunnen reageren en dan met name met eiwitten; dit noemen we de nietenzymatische versuikering van eiwitten oftewel de niet-enzymatische glycering (dia 15). Een eiwit bestaat uit een lange kraal van verschillende aminozuren, hier weergegeven in het rood met daarin de codering van het aminozuur. Glucose, weergegeven in het blauw kan reageren met sommige van deze aminozuren zoals met de aminozuren lysine en arginine. Dit zijn in essentie vrij eenvoudige spontane reacties die altijd en overal plaatsvinden. Een mogelijk bekend voorbeeld van deze versuikeringsreactie is de vorming van versuikerd oftewel geglycosyleerd hemoglobine. Het geglycosyleerd hemoglobine oftwel HbA1c wordt namelijk door dokters veelvuldig gebruikt als een maat voor de glucoseconcentraties in het bloed over de laatste 6 tot 8 weken.

Zulk soort versuikerde eiwitten kunnen verdere chemische veranderingen ondergaan tot uiteindelijk een grote verscheidenheid van stabiele eindproducten zoals de lysine modificaties CML, CEL en de cross-link pentosidine, weergegeven in het groen. Deze laatste stap in de reactie is onomkeerbaar en als gevolg hiervan hopen deze versuikerde eiwitten zich op in het lichaam. Dit proces kan jaren duren. In het engels worden deze versuikerde eiwitten weergegeven met het acroniem AGEs; in wetenschappelijk jargon advanced glycation endproducts.

Curieus genoeg komt onze kennis over deze niet-enzymatische glyceringsreactie uit de voedingsindustrie (dia 16). In 1912, dus precies honderd jaar geleden, publiceerde Louis-Camille Maillard een artikel waarin hij voor de eerste keer de interactie van glucose met eiwitten beschreef. Dit verhaal is de geschiedenis ingegaan als de Maillard reactie of de nietenzymatische bruiningsreactie. Maillard (1878-1936), een Frans medicus en chemicus, geboren in het schilderachtige dorpje Pont-a-Mousson nabij Nancy, ontdekte dat tijdens de bereiding van voedingsmiddelen door verhitting er een reactie plaatsvindt tussen suikers en eiwitten. Het product dat ontstaat, is verantwoordelijk voor veranderingen in de kleur en de smaak. Kortom, de smakelijke korstje van een stuk roodvlees is het gevolg van een ingewikkeld proces van versuikering. In 2005 publiceerde columniste Sylvia Witteman een kookboek getiteld: "De Maillard reactie" (dia 17). Ze schrijft in haar voorwoord letterlijk: "Waarom heeft dit boek dan zo'n rare, ja zelfs moeilijke naam?" Ze geeft een verdere toelichting: ik citeer "Maillard, een Franse chemicus zag zowat een eeuw geleden dat een heleboel voedsel er enorm in smaak op vooruit gaat als het snel en hevig verhit wordt. Het verschil tussen een kille plak van een koe en een hongerverwekkende biefstuk. Tussen saai graan en opwindend bier. De opwekkende geur en smaak van koffie zou niet bestaan zonder deze Maillard reactie". Helemaal waar, maar dan ontspoort Witteman door te schrijven "dat alles berust op toeval en dat we aan die inmiddels morsdode Maillard ook maar iets te danken hebben". Maar daarmee doet ze Maillard ernstig tekort; hij heeft aan de basis gestaan van ons begrip over het versuikeren van eiwitten. De Maillard reactie is uitgebreid beschreven in honderden publicaties. Dus, een proces van versuikering wat dus 100 jaar geleden werd beschreven in relatie tot voeding, vindt dus ook plaats in het lichaam. Dit proces in het lichaam gaat natuurlijk veel minder snel en heftig dan in een braadpannetje, maar toch, de reactie is vergelijkbaar. Het waren Prof Antonie Cerami en Prof Vincent Monnier die in de jaren '70 van de vorige eeuw de basis hebben gelegd voor de huidige kennis over de vorming van deze versuikerde eiwitten in het lichaam en de consequenties daarvan voor onze gezondheid.

Vele studies inmiddels hebben een toename van deze versuikerde eiwitten aangetoond in diabetes en wijzen op een belangrijke rol van deze versuikerde eiwitten in het optreden van complicaties van hart- en bloedvaten. Zoals gezegd, een belangrijke eigenschap van deze versuikerde eiwitten is dat ze met andere eiwitten dwarsverbindingen vormen tot zgn cross-links zoals pentosidine. In de jaren 90 konden wij in samenwerking met de groep van Johan te Koppele in Leiden al aantonen dat pentosidine in diabetes verhoogd is t.o.v. een gezonde controlegroep (dia 18). Opvallend was dat er ook in de controles een toename te zien was van pentosidine met de leeftijd, maar in de diabetes patiënten was de toename significant hoger dan in de controle groep. Kortom, deze versuikerde producten komen bij ons allemaal voor, nemen toe met de leeftijd, en dit gebeurd sneller in patiënten met diabetes.

Versuikering van eiwitten leidt ertoe dat de eiwitten hun functie minder goed kunnen uitvoeren, ze "verouderen". Een verouderingsproces dus, dat is het versuikeren van eiwitten eigenlijk. Als huid 
bijvoorbeeld ouder wordt, zie je dat ze minder soepel wordt (dia 19). Daar zorgen onder meer versuikerde collageenvezels voor cross-linking en verharding en maakt de huid minder flexibel. Dit is de reden waarom ook de cosmetische industrie geïnteresseerd is in deze versuikeringsreactie en al producten aanprijzen die ingrijpen op dit proces, zoals wordt geadverteerd in toonaangevende internationale literatuur zoals hier in de Vlaamse editie van Marie Claire (dia 20). Hoewel er totaal geen wetenschappelijke onderbouwing is (dia 21) claimt Chanel een werkstof gevonden te hebben die versuikering van de huid kan tegengaan. Dit tekent trouwens het opportunisme van de industrie om te komen met nieuwe producten.

Datzelfde proces van versuikering en cross-linking van collageen, wat ik inzichtelijk heb proberen te maken met de veroudering van de huid, speelt zich ook af in de bloedvaten (dia 22). De veronderstelling is dat de bloedvaten stijver worden door versuikerde cross-links van het collageen en daardoor minder goed kunnen ontspannen. De consequenties hiervan werd in de eind jaren ' 90 al uitvoerig onderzocht in Maastricht door Prof Wolffenbuttel, Dr Maya Huijberts en prof Harry Struijker-Boudier. Zij waren een van de eersten die konden aantonen dat cross-linking door versuikering in de bloedvaten leidt tot o.a hoge bloeddruk en hartfalen.

Een tweede mechanisme waarmee deze versuikerde eiwitten in verband wordt gebracht met complicaties aan hart- en bloedvaten is de binding van deze versuikerde eiwitten aan specifieke bindingseiwitten op cellen in het lichaam, waarvan de receptor voor AGEs (RAGE), de belangrijkste is. Deze receptor werd in 1992 ontdekt door Prof Annemarie Schmidt. De binding van versuikerde eiwitten aan deze receptor leidt tot een directe activering van endotheelcellen met functieverlies van de cellen tot gevolg en het ontstaan van hart- en vaatziekten. Ondanks de vele publicaties in de literatuur hebben wij echter nooit een directe binding van versuikerde eiwitten aan deze receptor op endotheelcellen kunnen vaststellen. Tot op de dag van vandaag heb ik daar trouwens nog geen verklaring voor; én dat voor een professor. Zoek de verschillen; ook dat is wetenschap.

Maar zo'n zoektocht heeft ook een positieve keerzijde. Door de vele experimenten hebben we mijn inziens nog een zeer belangrijk derde mechanisme opgelicht, waarmee deze versuikerde eiwitten in verband kunnen worden gebracht met complicaties aan hart- en bloedvaten (dia 23). Ik heb $u$ eerder verteld dat insuline nodig is voor de opname van glucose in cellen. Echter, endotheelcellen vormen hierop een uitzondering; de opname van glucose in endotheelcellen is namelijk onafhankelijk van insuline. Dit betekent dat een toename van glucose in het bloed direct zal leiden tot een toename van glucoseconcentraties in de endotheelcellen. Noem het de zoete inval. En dit heeft grote consequenties. Hier zal ik verder op ingaan.

In elke cel wordt glucose in de glycolyse afgebroken en dit levert energie op in de vorm van ATP. Maar door een te hoge concentratie van glucose ontstaan in cellen glucose afbraakproducten zoals het glucose afbraakprodukt methylglyoxaal. En hier gaat het om. Dit eenvoudige molecuul methylglyoxaal is veel reactiever en sneller dan glucose in het versuikering van eiwitten. In tegenstelling tot glucose kan methylglyoxaal binnen minuten leiden tot versuikering van eiwitten. Gebaseerd op onze experimenten van de laatste jaren ben ik ervan overtuigd dat een toename van methylglyoxaal in de cellen een boosdoener is, en mogelijk de grootste, in het ontstaan van complicaties aan de hart- en bloedvaten. Dit onderzoek is de afgelopen jaren leidend geweest. Zo laat recent onderzoek van Dr Olaf Brouwers uit mijn onderzoeksgroep zien dat een stapeling van methylglyoxaal in endotheelcellen leidt tot meer versuikering van eiwitten, tot disfunctie van de endotheelcellen en tot meer complicaties aan de ogen en de nieren.

In een te hoge concentratie is methylglyoxaal schadelijk en dit kan ik het beste illustreren aan de hand van een anekdotisch voorbeeld en is tevens een opmaat voor de geschiedschrijving van de Interne Geneeskunde in Maastricht.

Dat honing de eigenschap heeft om bacteriën te doden, is al eeuwen lang bekend. Maar, hoewel de honingpot 'de beste huisapotheek' genoemd word, heeft honing nooit de status van officieel erkend geneesmiddel gekregen. In het laatste kwart van de vorige eeuw echter, werden als maar meer gevallen gesignaleerd van niet-genezende wonden, doordat de infecterende bacteriën resistent geworden waren tegen de aangewende antibiotica. Toen begonnen onderzoekers zich af te vragen of ze de oplossing voor dit probleem misschien kon vinden in de behandelingwijzen uit het verre verleden. Zo ook in Maastricht. Het werd het levenswerk van Dr. Postmes, 
biochemicus en tot zijn dood in 2002 researchmedewerker van de afdeling interne geneeskunde. Op zijn zoektocht naar betere behandelingwijzen voor moeilijk geneesbare wonden zag hij in honing een vruchtbaar researchonderwerp. Maar zijn academische omgeving reageerde met scepsis. Tot een merkwaardig voorval een opening creëerde. Het toenmalige hoofd en oprichter van de afdeling Interne geneeskunde, de inmiddels overleden hoogleraar Prof Flenderig, werd in een restaurant om hulp gevraagd nadat een kokkin gloeiend vet over haar arm had gekregen. Prof Flenderig herinnerde zich Postmes' honingverhalen en adviseerde de brandwond met honing in te smeren en daarna te verbinden. $\mathrm{Na}$ een aantal weken was de wond perfect genezen en Flenderig was op slag overtuigd. Dr Postmes kreeg vervolgens carte blanche voor zijn onderzoek.

Maar er zijn verschillende soorten honing zo ook Manukahoning (dia 24). Het bijzondere aan Manukahoning is de sterke antibacteriële werking. De honing heeft een unieke smaak, en is veel donkerder dan klaverhoning. In 2008 identificeerde professor Thomas Henle van de Universiteit van Dresden, het antibacteriële stofje in de honing als zijnde methylglyoxaal. De hoeveelheid methylglyoxaal in de medicinale Manukahoning staat nu vermeld op het lábel. Zelfs het AMC in Amsterdam probeert met deze vinding personeel te werven, zoals te lezen is in een advertentietekst in de Volkskrant. Kortom, met dit voorbeeld heb ik duidelijk willen maken hoe schadelijk methylglyoxaal kan zijn; het is toxisch en in een te hoge concentratie kan het cellen doden.

Methylglyoxaal heeft de laatste jaren onze onderzoeksagenda enigszins bepaald. En terecht; (fig 25); methylglyoxaal is dus veel reactiever dan glucose in het versuikeren van eiwitten, zoals geillustreerd in een experiment waarin we eiwit hebben laten reageren met glucose of met methylglyoxaal Ik voorspel $\mathrm{u}$ dat de komende jaren zal worden vastgesteld dat methylglyoxaal een prominente rol speelt in het ontstaan van hart en vaatziekten en dat gaat verder dan alleen in diabetes.

Maar het lichaam is sterk en kan zich op een natuurlijke wijze wapenen tegen teveel methylglyoxaal. $\mathrm{Er}$ is namelijk een beschermingseiwit, en dit eiwit heet glyoxalase 1, dat in staat is dit methylglyoxaal af te breken tot het onschuldige d-Lactaat. (dia 26). Wanneer we dit beschermingseiwit tot overexpressie brengen in kleine proefdieren dan zien we ook een daling van methylglyoxaal. Veel belangrijker nog, we zien een verbetering van de functie van de bloedvaten, experimenten die we trouwens hebben uitgevoerd in samenwerking met Prof Jo de Mey van de farmacologie. We zien ook minder complicaties aan de ogen en de nieren ${ }^{15,16,17}$. Maar helaas, dit beschermingseiwit laat het ook weleens afweten. Juist onder condities van chronische ziekten zoals diabetes zien we dat dit beschermingseiwit veel minder functioneert met als gevolg een toename van methylglyoxaal en versuikering van eiwitten met alle consequenties van dien. In diabetes zorgt niet alleen een toename van glucose maar ook het falen van dit beschermingseiwit glyoxalase-1 voor een toename van methylglyoxaal en van versuikerde eiwitten.

Maar ook tijdens de veroudering vinden we een afname van dit beschermingseiwit. In samenwerking met het onderzoeksteam van 's werelds belangrijkste ouderdomsprofessor Jan Hoeijmakers in het Erasmus Medisch Centrum in Rotterdam is gevonden dat de expressie van glyoxalase 1 is verlaagd in cellen afkomstig van patientjes met een verouderingsziekte, verwant aan progeria. Deze ziekte zorgt voor extreem versnelde veroudering. Kinderen die lijden aan deze ziekte krijgen al vroeg last van ouderdomsverschijnselen en worden gemiddeld niet ouder dan twaalf jaar. Wij vonden in deze cellen een verhoging van methylglyoxaal en versuikerde eiwitten. De toename van methylglyoxaal speelt mogelijk eens belangrijke rol in het proces van versnelde veroudering. Later werd door anderen aangetoond in het wormpje de C.elegans dat een toename van glyoxalase 1 en een afname van methylglyoxaal, het wormpje langer laat leven; geen 13 dagen, zoals de doorsnee worm, maar 17 dagen. Dus, een afname van het beschermingseiwit glyoxalase 1 en een toename van methylglyoxaal is betrokken bij veroudering. Daarom is het ook niet verwonderlijk dat we in typische ziekten geassocieerd met veroudering zoals artose en Alzheimer, maar ook in atheroscelrose en in kanker een toename zien van versuikerde eiwitten.

Recent onderzoek door ons uitgevoerd in samenwerking met de groep van prof Hans Niessen van het VUMC in Amsterdam laat ook zien dat in acute condities zoals tijdens een hartinfarct de 
vorming van methylglyoxaal een mogelijk belangrijke rol speelt in schade aan het hart na een infarct. Wanneer we in kleine proefdieren methylglyoxaal na een infarct verlagen, zien we een afname van wel $50 \%$ van de grootte van het infarct. Een verlaging van methylglyoxaal is dus heel gunstig. Ik zal dit zeer relevante onderzoek, ik hoop dat $u$ dit met me eens bent, de komende jaren continueren.

Versuikering van eiwitten vanuit glucose en dus ook methylglyoxaal is echter maar een gedeelte van het verhaal. Eerder onderzoek van prof John Baynes uit North-Carolina heeft aangetoond dat de vorming van deze versuikerde eiwitten ook vanuit vetten kan ontstaan. In dit geval is het acroniem AGEs minder van toepassing en kunnen we meer spreken over advanced lipoxidation end products, maar de gevormde versuikerde produkten zijn hetzelfde. Zo heeft Dr Katrien Gaens in haar promotieonderzoek in mijn onderzoeksgroep inderdaad recent kunnen aantonen dat versuikerde eiwitten zich ook ophopen in het buikvet (dia 27). In ben ervan overtuigd dat de door haar aangetoonde ophoping van deze versuikerde eiwitten in het buikvet vergaande consequenties heeft. Eerder heb ik $U$ gemeld dat we het antwoord nog niet precies weten hoe overgewicht nu leidt tot insuline resistentie en diabetes. Wij hebben met dit onderzoek sterke aanwijzingen dat de ophoping van deze versuikerde eiwitten een belangrijke rol speelt in het vrijmaken van stofjes in het buikvet, die vervolgens kunnen leidden tot insuline resistentie en type 2 diabetes.

Ik hoop dat ik $\mathrm{u}$ heb kunnen overtuigen van één van de grootste gezondheidsproblemen van deze tijd die voortkomt uit disbalans; $\mathrm{nl}$ zwaarlijvigheid en diabetes en het hieruit voortkomende hoge risico voor het ontstaan van hart- en vaatziekten en de rol die het versuikeren van eiwitten hierin spelen. Kunnen we dan hier iets aan doen? Het antwoord is een voorzichtige ja. Met een goede metabole instelling van diabetes patiënten zal een versnelde vorming van versuikerde eiwitten in het lichaam kunnen worden geremd. Het is ook aannemelijk dat met gezonde voeding, niet teveel eten en voldoende bewegen veel winst te behalen is. Daarnaast zijn medicijnen in ontwikkeling, die beogen in te grijpen in de vorming van versuikerde eiwitten danwel bestaande cross-links door versuikering te breken. Interventiestudies in kleine proefdieren met diabetes laten gunstige effecten zien; de grote bloedvaten worden weer soepel en elastisch en het leidt tot minder complicaties aan hart- en bloedvaten. Maar in mensen zijn we helaas nog niet zover. Het is een lange en moeizame weg, maar er wordt hard aan gewerkt.

Mijn verwachting is dat in de toekomst de focus enigszins zal verschuiven van het behandelen van ziekten naar een subtielere behandeling in een vroeg stadium van de ziekte. Hiervoor is het nodig de personen te identificeren met een verhoogd risico voor ziekten. Ik heb u eerder verteld over biomarkers. Mijn verwachting is dat nieuwe biomarkers in het bloed gebruikt zullen gaan worden in de toekomst om het risico voor complicaties en ziekten beter in te schatten. Voor het vinden van nieuwe krachtige biomarkers, zijn metingen in grote groepen mensen, gezonde controles en patiënten, die gevolgd worden in de tijd, noodzakelijk; zogenaamde prospectieve cohorten. De recent gestarte Maastricht Studie (dia 29) met Dr Miranda Schram als projectleider, in zo'n grote studie waarin de deelnemers voor een lange periode worden gevolgd. De Maastricht Studie is een uniek onderzoek onder de Zuid-Limburgse bevolking naar de oorzaken van type 2 diabetes, hart- en vaatziekten en andere chronische aandoeningen. Dit is het grootste onderzoek in zijn soort in de wereld. Centraal staat de vraag waarom de ene persoon wel type 2 diabetes ontwikkelt en de andere niet en wanneer er al sprake is van diabetes, waarom de ene persoon wel hart en vaatziekten ontwikkelt en de andere niet? Het vinden van voorspellende nieuwe biomarkers hiervoor is één van de speerpunten van dit onderzoek. In de Maastricht Studie zullen we o.a ook versuikerde eiwitten gaan meten in het bloed met behulp van geavanceerde massaspectrometry, allemaal mogelijk door de specifieke expertise van Jean Scheijen (dia 30). Daarnaast meten we versuikerde eiwitten in de huid. Veel versuikerde eiwitten vertonen $\mathrm{nl}$ fluorescentie karakteristieken en daar maken we gebruik van door op de huid met een lampje deze versuikerde eiwitten te meten. Mogelijk kunnen we versuikerde eiwitten als voorspellende vroege biomarkers voor het krijgen van hart- en vaatziekten gaan gebruiken. Ik ben ervan overtuigd dat dit onderzoek uiteindelijk een belangrijke bijdrage zal leveren in de strijd tegen diabetes en hart- en vaatziekten.

Ik vertelde $\mathrm{u}$ al, wetenschap is topsport. Er moet gepresteerd worden. En we spelen in een zware competitie. U moet weten dat ook wij onderzoekers worden afgerekend op geleverde prestaties, 
en dat is een goede zaak, hoewel hier ook Stapeliaans gevaar dreigt. De gevraagde prestaties zijn niet gering; die gaan over het aantal publicaties per jaar, inkomsten vanuit subsidies en liggen er op het gebied van onderwijs. Als $u$ weet dat slechts $10 \%$ van subsidieaanvragen bij subsidiegevers zoals het Diabetes Fonds Nederland succesvol zijn, begrijpt $U$ dat je van zeer goede huizen moet komen om in de prijzen te vallen. $\mathrm{Er}$ is een extreme competitie voor de helaas beperkte beschikbare middelen. Ook heel goede projecten met goede scores van referenten worden afgewezen.

Ook het publiceren in gerenommeerde tijdschriften met een hoge impactfactor is geen sinecure. Zo worden meer dan $50 \%$ van de ingediende manuscripten voor publicatie in het tijdschrift Diabetologia (dia 31) al bij het indienen in een eerste screening geweigerd. Uiteindelijk wordt slecht $18 \%$ van de ingediende manuscripten geaccepteerd en ook daadwerkelijk gepubliceerd.

Het is een wedstrijd. Maar als het lukt, je haalt een subsidie binnen of je publiceert in één van de toptijdschriften, en dat gebeurt ons gelukkig veel vaker dan gemiddeld, dan is de euforie ook groot. Het voelt alsof je hebt gescoord. Wetenschap is bovenal een teamsport en deze boodschap werd gedurende jaren het beste uitgedragen door de voetballers van Manchester United, die met de AIG, de algemene interne geneeskunde, op hun shirt, grote prijzen hebben gewonnen (dia 32).

Met name onderzoeksfinanciering van het DFN en van de topinstituten CTMM en TIFN heeft het mij mogelijk gemaakt een onderzoeksteam samen te stellen waarin we met verschillende expertises toponderzoek kunnen doen.

Echter, het verkrijgen van voldoende financiële middelen voor het doen van onderzoek vormt een grote zorg. De voortekenen zijn niet erg rooskleurig. Uit cijfers die het Rathenau Instituut recent publiceerde, zal het Rijk in de periode 2012-2016 veel minder geld uitgeven aan wetenschappelijk onderzoek. Opgeteld besteden de ministeries in 2016 nog 4,4 miljard euro aan onderzoek, een daling van 700 miljoen ten opzichte van 2010. Het verkrijgen van externe gelden vanuit contractinkomsten met bedrijven, de collectebusfondsen en met name Europese fondsen, de zgn derde geldstroom, is meer dan ooit een noodzaak. Hiervoor is een bundeling van krachten en expertises het credo. Het biedt dus ook kansen en nieuwe mogelijkheden. Ik pleit er ook krachtig voor dat we de virtuele muren tussen onderzoeksinstituten CARIM en NUTRIM slechten en dat we komen tot een bundeling van het metabool en cardiovasculaire onderzoek. Dit is goed mogelijk met behoud van eigen identiteit. Dit is mijn inziens essentieel om de strijd te kunnen aangaan voor het verkrijgen van de schaarse externe middelen. Het doet me dan ook veel genoegen dat we recent in samenwerking met Prof Ronald Mensink binnen TIFN-next voor de eerste keer een gemeenschappelijk project van CARIM en NUTRIM gehonoreerd hebben gekregen. Hier ligt de toekomst.

Mijnheer de pro-rector, dames en heren,

Ik hoop dat ik $U$ mijn fascinatie voor het onderzoek heb kunnen overbrengen. Het is een combinatie van enthousiasme voor het intellectuele werk, de spanning, de uitdaging, de nieuwsgierigheid. Ik hoop dat $\mathrm{u}$ overtuigd bent geraakt van het grote belang van de versuikering van eiwitten voor het ontstaan en verloop van ziekten, en dat dit verder gaat dan diabetes. Het meeste onderzoek staat nog in de kinderschoenen, maar ik houd $\mathrm{U}$ zeker op de hoogte.

Daarmee kom ik aan het einde van mijn rede.

Ik ben velen dank verschuldigd. Ik heb het grote geluk gehad in mijn wetenschappelijke carrière dat ik altijd omringd geweest ben door grote inspirators

Ik wil beginnen met mijn helaas veel te jong overleden promotor professor Henk van de Bosch (dia 33). Hij was mijn grote leermeester en inspirator. Ik had het niet beter kunnen treffen. Hij heeft me opgeleid in de biochemie, gestimuleerd en geadviseerd. Ik heb heel veel geleerd van zijn manier van werken en ik probeer het lab te leiden in de stijl van Henk. Mijn dank aan Henk is zeer groot en mijn buiging voor hem is diep. Het doet mij heel goed dat Wilmy vandaag aanwezig is.

Ik dank prof Victor van Hinsbergh. Beste Victor, eerst bij TNO in Leiden en later op de VUMC in Amsterdam was jij mijn mentor op het gebied van endotheel onderzoek. Jou kennis op dit gebied 
is ongeëvenaard. Ik realiseer me dat we in 1994 zijn begonnen aan dit onderzoek en onze volharding toen is de basis geweest van mijn werk en succes van nu.

En Prof Dr Coen Stehouwer, afdelingshoofd van de Interne Geneeskunde. Beste Coen, 18 jaar geleden zijn we in Amsterdam begonnen aan onze succesvolle samenwerking. Jij hebt me ook naar Maastricht gehaald en we hebben ons werk voortgezet en verder uitgebreid. Ik dank je voor het bijna blindelings vertrouwen dat je hebt in mij. De ruimte die jij mij geeft, maakt dat ik hier nu sta. Onze expertises zijn complementair. Je overtuigingskracht gebaseerd op kennis en visie zijn ongeëvenaard. Een groter compliment kan ik niet maken. Ik heb groot respect hoe jij onze grote afdeling in deze tijd van hectiek leidt.

Ik ben ook de benoemingscommissie erkentelijk voor hun vertrouwen in mijn benoeming.

Ook noem ik graag de medewerkers van de Afdeling Klinische Chemie van het VUMC met afdelingshoofd Prof Rien Blankensteijn, die mijn werk in het Amsterdamse mogelijk hebben gemaakt en waar de basis is gelegd voor de organisatie van mijn huidig lab. En dat deed ik in samenwerking met een team van bevlogen onderzoekers met een speciale dank aan Prof Hans Niessen, Dr Tom Teerlink, Dr Peter Scheffer, Astrid Kok en Jan van Bezu.

Zoals gezegd; wetenschap is ook een teamsport. Een sterke interactie tussen de basale wetenschappers, de epidemiologen, de dokters, de analisten is essentieel. Voor mijn huidig onderzoek in Maastricht had ik me geen betere en stimulerende omgeving kunnen voorstellen. Ik werk in een team waar ik trots op ben. Op deze foto staan leden van team en het team is onze grote kracht. Allemaal ontzettend bedankt; ik kan niet zonder jullie. (dia 34).

Maar ik zou hier niet hebben gestaan zonder familie. Mijn jeugd op de Kanis is de basis geweest van mijn wetenschappelijke carrière. Ik was bevoorrecht en ik wil mijn moeder en mijn helaas te vroeg overleden vader hiervoor bedanken. Zij hebben de mogelijkheden gefaciliteerd die deze eigenzinnige jongen had uitgestippeld.

En dan Pim, Raven, Tos; mijn wachtwoord en mijn stoere jongens op de eerste rij. En daar draait het pas echt om in het leven, jullie zijn de toekomst. Ik ben trots jullie vader te zijn.

Mijn allergrootste grootste dank gaat uit naar mijn draaiende motor, Hermine, mijn steun en toeverlaat. Hermine, we zijn samen dit avontuur aangegaan en zonder jou had ik zeker hier niet gestaan. Dit is voor jou.

Ik heb gezegd. 